\title{
Bodies, Space, and Remembrance
}

Nur Turkmani

\section{Abstract}

In this article, Nur Turkmani's reflects on the ways that Lebanese streets became a place of intimate encounters during the October 2019 Thawra. Turkmani traces the various threats to the body, from the threats of police violence during the Thawra to the immunological threats of COVID-19 as people continued to reclaim public spaces during the early months of 2020 , and how women's bodies were often at the center of these spaces.

Keywords: Gender, Lebanon, women, Women Bodies, Public Spaces, Revolution

To cite this paper: Nur Turkmani , "Bodies, Space, and Remembrance ", Civil Society Knowledge Center, Lebanon Support, December, 2021 . DOI: 10.28943/CSR.005.007.

[ONLINE]: https://civilsociety-centre.org/paper/bodies-space-and-remembrance

Much of how we make sense of the world is through our bodies. How they wrinkle and stretch to mark time and movement; how they flatten into stacks when numb; how they relate to and cluster around one another in celebration and mourning. This year, I thought of bodies a lot. Bodies as in being born into womanhood; bodies as in who around me is frail, who might we kill if we catch the virus; bodies as in there are human beings trapped under buildings; bodies as in limbs on limbs marching from Hamra to The Ring Bridge; bodies as in what does it mean to sit alone, isolated, in order to survive?

An odd, kinetic image comes to me when I think of Lebanon this year: our bodies sticking together like one shapeless blob of Playdough, and then spreading and thinning over time before violently separating into chunks. The coming together into a blob marks how our year started: October 2019, when we were lumped in the streets, in Riad el Solh and Sahet el Nour and Elia Square and Jal el Dib and Nabatieh and Alay and Saadnayel and Halba, familiarizing ourselves with what it means to say these streets belong to you and me, these streets are a space for negotiation, for back and forth-ing, for gendering, and for what we will make of them. The year then breaks in March - this moment of global humbling, to quote Zadie Smith (2020) - where everything we had been working towards dilutes, and we are forced to backtrack, to return to the private, the private where so much of our womanhood is silenced and controlled and contorted. And then August 4th, where we lose all sense of meaning, all sense of the body.

Last year, on the 8th of March, my friends and I gathered around Mathaf for the annual International Women's Day march in Beirut. We should not have been there. The march - which, for the past couple of years, has been organized by an incredible group of intersectional feminists across Lebanon - was officially canceled. There had been over two dozen coronavirus cases in the country by then, and though we were not officially in lockdown, the potential effect the virus could have on us was becoming 
clearer. The wiser choice would have been to stay at home. But that morning, my group of friends, with whom l'd spent the year organizing and writing and protesting with, somehow convinced each other to go. We knew it was not right to go, but there was an urgency: a sense of youthful entitlement (what could the virus possibly do to us?) and of commitment (this matters, this really matters). Arriving at Mathaf was a reenactment of that familiar revolutionary euphoria, which had slightly wavered in the two months leading up to International Women's Day. Nadine, a feminist activist l'd been seeing in the streets for over four months, was chanting into the megaphone: "Freedom, freedom, we want freedom; the state can't dictate what we do, nor can any religious institutions, I want freedom, freedom." And so, in the middle of chants and drums and laughter, we danced and laughed and marched like flamingos from Mathaf to Riad el Solh, both flaunting our existence and demanding a better world. Something about that day stands out - it felt limitless and uncontained, but grounded in love, worlds, and worlds of love. Sort of what you might imagine the last day on earth to be, if all of us were to disappear (and less than one week later, the whole world did, in a way). More than anything, it reasserted what the October 17 revolution had meant to many of us: it was feminist; it was tender; it was radical; it was joyful. Particularly, for women and other groups who have long found the streets disdainful and dangerous, that day, and many of the days that had preceded it, was a negotiation, a redrafting, of what public spaces could or ought to be.

Hannah Arendt (1958) would say that this - this coming together in the streets, this process of collective recreation - is the human gift of beginning anew. I cannot claim to be an Arendt specialist, but much of my understanding of the public space comes from her. In The Human Condition (1958), Arendt conceives of politics as one based not on satisfying individual needs or agreement on shared notions, but rather, one rooted in collective and community-based deliberation. She takes her nostalgia for the Greek polis and does something with it - she argues that something about people coming together to reflect and decide upon their collective experience captures what politics and political activity should strive to be. "The polis," she writes, "properly speaking, is not the city-state in its physical location; it is the organization of the people as it arises out of acting and speaking together, and its true space lies between people living together for this purpose, no matter where they happen to be" (198-199). The polis, then, as something transformative and transportable.

I reread Arendt now and think of the Arab Spring, and of Lebanon's October revolution. In the early days, the revolution was a "space for appearance," to quote Arendt again (1958), that made us more accessible to one another (204). In the months following October 17, we broke the postwar passive nostalgia and decades of political impasse to create a community of narratives and shared memories, stories. Empty spaces were occupied: abandoned theatres, parking lots, and public squares. We used them to see one another: to look at the baggage we had each hauled over the years, and to ask each other about the contents of this baggage.

One night, after work, I went alone to one of the tents at the square and sat on a chair, quietly, listening to a lecture by an economist. I remember having no expectations - simply inhabiting a spot for the evening. After the talk, which was on corruption in the oil sector, an old man stood up, slightly shivering, and spoke into the microphone about how un-dignifying his job has been. His comment was unrelated to the lecture itself, but his urgency and affliction washed away my momentary passivity. Arendt, in a footnote of The Human Condition, refers to an anecdote by the philosopher Demosthenes, who comes into contact with a man telling him of his physical pain after a beating. When Demosthenes responds 
that the man "suffered nothing" of this, the man cries out, "I suffered nothing?" It was only when the man's pain was clearly visible in his voice that Demosthenes was capable of compassion (Schoonheim 2019). The old man at the square told us of the long hours, the minimal pay, the lack of protection, and how he reflects on his life and thinks of it as void. How crucial it was for him to speak; how crucial for us to listen to what he had to say. A micro solidarity of sorts unfurling, like a lightweight carpet, in the middle of downtown Beirut - a plot of land which for decades has been described by the country's residents as spectral and inaccessible.

Imagine, then, what it meant for us to see downtown as a place of pride and contestation, a place that street vendors and artists and intellectuals and "thugs" all had equal claims to. The squares across the cities and towns transformed into places where we could try to understand and address the financial crisis, climate change, labor laws, and custody rights for women. Mona Fawaz and Isabella Serhan (2020), in their piece "Urban Revolutions: Lebanon's October 2019 Uprising," talk about how keen activists were to "challenge privatopia," and to reclaim previously closed-down public venues, such as the Egg, into "sites of discussion and mobilization". Activists were also keen to reclaim private spaces, such as land lots "earmarked for development," to reimagine and even reverse these fabricated private-public boundaries; to "embody an alternative political imaginary, one where being together is based on the shared aspirations of a life in dignity and mutual respect." Without even trying, the protests across the cities depicted gentrification, severe class and urban segregation, the patriarchal skeleton of our streets, the infrastructure that prioritizes the real estate sector over its people, the lack of public transportation, and the deterioration or absence of public spaces. The contradictions of our cities were exposed like freckles under the sun. The public space, as we had experienced it during the protests, allowed us to think of who we are individually and what our collective tensions are - and also, how they can be transgressed or sidestepped.

What does it mean for women to dance late at night on bridges and in squares, and not at private clubs or women-only weddings - how does that shift the way we view and understand our bodies? What does it mean to say, you know what, this highway that cuts across east and west is a space for us to camp overnight, to lay down underneath a tent of stars and to sing into the sky? What does it mean for working-class men to breakdance in the streets, to rap alongside radical feminist groups? It changes you. It changes your relationship to your city, and it changes how you flit around the public space.

As women, we experienced this process of cultural production and reclamation in an almost exponential sense. Though we have long been a part of this country's social and political fabric, the public space has for many of us been either inaccessible or crushing. Feminist protests and spaces were mostly privatized or compartmentalized, and - as is commonly the case - we feared the streets. The very system has long privatized gender issues, regulating and relegating them to our private lives through the personal status laws. But it was clear from the beginning that there is no revolution while women are second-class citizens unable to pass citizenship to their children or foreign husbands, or if women cannot decide what they do with their bodies. There is no revolution while refugees are harassed and prevented from working, and there is no revolution while migrant domestic workers have their passports taken away from them by their employers. In the streets, we stared at the patriarchy straight in the eye. Our enemy - what we wanted to bring down - was a multi-tentacled one. The very first night of protests, a woman had kicked an armed bodyguard straight in the groin. As the days went on, women became human buffers between riot police and protesters. Women led neighborhood marches, women 
organized meetings, and women negotiated with lawyers for the release of detainees. Though women had been organizing for decades, they still struggled with the barricades blocking their way out into the public. This revolution, then, was also about us going underneath, above, and ultimately destroying these barricades. It was about taking to the streets to say: we decide, not you. Unlike other uprisings or social movements in the region or in the country's past, we did not shy away, and our political demands were not narrow.

Arendt (1958) says that this web of human relations - that these new forms of collective action or interactions with one another in public spaces - is an artificial act, and is fundamentally symbolic, but through it we are able create new language to articulate meaning and coordinate between one another. There is something liberating about how much Arendt stresses the artificiality of public spaces and politics more generally; it is not necessarily natural for us to gather, but it is something to strive towards. The act of stepping out of our private lives and into a public space, for the sake of freedom, is for Arendt a rediscovered truth, the human capacity of rebirth. But for her, the public space is not simply a place to gather but also a space for the individual to meet the political (1963). There was one night where, in the middle of an El Rass concert in Azarieh, I got into a random argument about the Syrian regime with a teenager, who was probably not much older than 17. It started with us dancing and chanting together. Not too long after, I chanted down with the Assad regime and he paused, took a distance, and asked what that had to do with anything. Our conversation evolved into an argument, but toward the end we laughed it off right before my friends dragged me out. Though I look back at that memory with laughter - my midnight feud with a random teenager - there was something incredibly meaningful and human about our interaction. There are countless stories of the sort: my queer friend who called out a protester chanting about Gebran Bassil being gay, asking, "Why is gay an insult?" Little back-and-forths daily, our city a manifestation of our bodies and the different places they belong to, the ways they make sense of and respond to one another. Here, again, this notion that Arendt propels forward in her work (1958) - the public space as one of cultural production and citizen construction/reconstruction.

Cynthia Bou Aoun (2020) writes that "the reclamation of public space took different forms: the spatial (the occupation of squares and roads); the intellectual (the use of slogans and the organization of discussion circles); the symbolic (the entry into the Grand Theatre after the construction site's fencing was removed); the artistic (graffiti and music); and the spectacular (the human chain and the registering of the Ring Bridge as a house on Airbnb)." In that sense, the revolution - or feminism as a political movement - made use of the public space to reassert itself, whether through simply bringing individuals together; politicizing their "togetherness" through both symbolic and sociological means; or establishing the space for intellectual and political discussions.

Only two days after the International Women's Day protest, the first coronavirus-related fatality was announced and one week later, the country declared a state of medical emergency. Suddenly, after months and months of defining and negotiating our relationship with the public space, we had to return to the private. Arendt worries about a modernity that "threatens" the public space, these spaces of appearances, by reducing us into primal beings more interested in sustaining our lives than sustaining the collective. Lockdown shed light on this - this human tendency to say, "I need to protect what's mine before anything else." A stark shift, in comparison to what the revolution had taught us. Now, globally, forms of gathering are restricted. Proximity and the public have become a threat to our existence. Many people I spoke to said that the months in lockdown were marked by an emptiness, an 
abstract sense of loss. Among a myriad of things, we have also lost, it seems to me, the sense of seeing and being seen. In Lebanon, the pandemic came after months of exposure to one another. The public space we had invested in was one where we interacted with people who were not necessarily close to us - they were not simply family or friends, or those from our inner circles that we would continue to see throughout the lockdown - but more so the hundreds of people we had become acquainted with on the streets, sharing together a frayed understanding of how we would like our country to evolve. There is something human about what protests can do: that you end up recognizing faces and characters, being drawn to each other in a way that often feels natural. It is not that I want to seek out these people today; without a sense of their bodies, I sink into a grid, or what people in Beirut often refer to in everyday lingo as "a bubble." These peripheral connections that spurred in the months following October 17 grounded us in our city; the squares and streets and highways becoming like a local pub or communal kitchen.

I felt a familiar pang of jealousy looking at pictures of human-filled parks across the world. Research being done amid the pandemic is highlighting something we have always known but are now recognizing as key: how incredibly important public space is for our psychological and physical wellbeing, our capacity to make meaning and connect to others. This became even clearer during Lebanon's lockdowns: a city without public spaces is not a city. The pandemic made us realize how few safe and communal spaces there are for us. An often-cited statistic is that Beirut has only $0.8 \mathrm{~m}^{2}$ of green spaces, though the World Health Organization (WHO) recommends at least $9 \mathrm{~m}^{2}$ (Nazzal and Chinder 2018). The very few parks this country has were closed during the first waves of lockdown; even the Corniche was closed off. Ironically, though there are very few public spaces in Lebanon, our economy and social structure are very much based on informal human-to-human contact. This is why the haphazard lockdown policies were heavily protested across the country, particularly in cities such as Tripoli, which are generally deprived and neglected and reliant on the stretches of streets and social contact.

The juxtaposition between our relation to our bodies and others' during the revolution and pandemic was terrifying - the capacity of the body to be a bridge for both the brilliant and the bad. A string of questions resurfaced in this heightened isolation: who is able-bodied, who has comorbidities, who is exposed, who is lonely, who is out merging with other bodies, who is homeless? Even during the revolution, which bodies were overlooked or made invisible, their suffering deemed as irrelevant to the broader causes?

Interestingly, Arendt is read as someone averse to the body because it can limit our agency (Schoonheim 2019). She writes in On Revolution (1984), "The most powerful necessity of which we are aware in self-introspection is the life process which permeates our bodies and keeps them in a constant state of a change whose movements are automatic, independent of our own activities, and irresistible - i.e., of an overwhelming urgency" (59). If our bodies in the revolution felt untouchable, we were now being reminded of their fragility - bodies that transport viruses, bodies that rot, bodies that weep, bodies that feel desolated and uninhabited. In this sense, our time during the pandemic was a resistance to restraint, a pleading to be released from the body and its weaknesses.

And what of vulnerable people locked up in abusive homes, unable to escape? Nearly everywhere, there were reports of a surge in domestic violence, and curfews forcing many women to stay at home 
with their abusers. Feminists have long highlighted the gendered distinctions between the public and private spheres, and have equally shown how blurred (and limited) this categorical distinction is in reality (Pateman 1983; Joseph 1997). We have all been subjected, one way or another, to theories of the "domestic woman," she who manages what happens indoors (free of charge, of course) in order for the "strong man" to manage what happens outdoors. This is what was radical and long-lasting about the globally recognized second wave of feminism: it politicized the personal, zoomed in on the home, and opened it to public scrutiny to show how violent this division can be, and how the divide between private and public makes the political process patriarchal by design.

When there is little access to the public world (be it physical or even virtual), the spaces for bargaining with the patriarchy, to quote Deniz Kandiyoti (1988), become infinitely smaller and more difficult.

But, and here is the caveat, I think our experiences in the public space, prior to the pandemic, gave us a political and local language with which to discuss our despair. There was a connection between the government's treatment of coronavirus and the police state; there were linkages between domestic violence and personal status laws; and so on. The revolution and our feminist revolution, more specifically, "upset" the divisions between the world inside and the world outside.

On the 8th of August - four days after our capital city exploded from 2,750 tons of ammonium nitrate left at the Port of Beirut due to "grave mismanagement and neglect"; four days after time stopped; four days after everything we had been working towards turned to powder - we returned to the streets. If the 8th of March was about love, then the 8th of August was about anger. All of it, unrestrained and unhinged. There was this sense that they had taken everything away from us: our lives, our revolution, our hopes, our right to believe in our city. We wanted revenge.

For me, the 8th of August was about the complete disintegration of the body. I remember distinctly not having any sense or grip of my arms or legs since the 4th of August. My very being was marked by a pain and anger so blinding I could not be associated with any form of structure. Our public spaces - Martyrs' Square and Riad el Solh and The Ring - had transformed into what looked like a war zone. We carried slogans with nooses, and we meant it: there would never be justice with any of the warlords ruling over us. The response to our anger? More blood. Security forces shot rubber bullets and tear gas at us, as protesters threw rocks back at them. The fury cloaked the day like fog, and our pain had numbed us. Ambulances rushed in to pick up injured people, and doctors in Lebanon would announce that the force used by security forces was clearly lethal (Othman 2020). As day gave way to night, we stormed government ministries, and the standing Prime Minister called for early elections (of course, we all knew that this was futile). There had been no state for a long while, but never was it more obvious than it was at that point: it was us versus them, and anything in the middle would simply not work.

While it is common for communities to turn to each other for help and support in times of crisis, August 8th took that even further. Not only did we turn to one another for survival (because, of course, it was communities that cleaned up the streets and looked for the missing after the 4th of August, and not the state), but we also framed our anger in revolutionary terms. In her brilliant book, A Paradise Built in Hell (2010), Rebecca Solnit writes:

The word revolution in Chinese is ge ming; ge - to strip away - and ming - the mandate. A revolution 
not only removes a regime, but also tears away its justification for governing. So, too, does a disaster: since the Chou dynasty, earthquakes in China have often been seen as signs that the rulers had lost the mandate of heaven. (151)

By August 8th, though we had lost the right to our bodies, the disaster was all the more public because of our revolution. Not for a second did we hesitate to return to the streets, even though we were in the midst of a global pandemic, which had further entrenched the rift between the private and the public. We had come face-to-face with the truth we all know, but for some reason continue to sidestep: our fate is in each other's hands.

Thinking of the body is, on the one hand, the most nonsensical of acts. We cannot think outside of it, because all that we experience is in relation to it. But at the same time, using bodily experience as a point of reference over the last year and a half has been a way to understand what exactly is at stake. The past couple of decades have been a reflection and searing critique on the notion of individualism. $A$ lot of the pushback has been a rejection of the values that alienate us.

What struck me most about Arendt's theory is that the public space is not a means to an end. No, the public space and political activity are an end on their own. For Arendt, political freedom goes beyond the illusion of state sovereignty. It negates the notion that the public space is a point of mediation between citizens and governments; it is, rather, a space that creates and negotiates actively, while continuously evolving, the effort "to become human in the fullest sense." Five years after publishing The Human Condition, Arendt writes in her book On Revolution (1963) that "revolutions are the only political events which confront us directly and inevitably with the problem of beginning," because they are intrinsically about carving out new political spaces (21).

Not too long ago, I took a walk through downtown Beirut. I was thinking of how this year, the anniversaries of the Arab Spring stepped in and out like old friends who remind us of who we once were. The sort of friends we have shared so much with, know too well, and, now, have tired of. We don't try to make them stay; we know once they leave, they take too much, so we avoid looking into their eyes. Better to look to the left. But who would we have been without these friends, where would we have strayed, who would have given us all this hope, this despair? On my walk, the streets were empty; the metal barricades back up; the security forces scattered like sticks. Undoubtedly, this is largely because of the pandemic, but in Lebanon's case, its blankness is emblematic of a past we had desperately sought to destroy. Today we are living in a country barely surviving - from economic collapse to pandemic to complete political illegitimacy and back. But something is different about the space. The graffiti, the sense of alarm it carries: the presence of our bodies have marked it like a memory that refuses to die.

The pandemic and the explosion and the revolution have reminded us, all three in different ways, how conditioned we are by our bodies, especially in relation to the spaces they occupy. We continue to revert to the same questions about the past: what about all of this is real, was the past year a lie, did we really protest, did we really break through these gender binaries, are we back to the cycle of "the revolution was all a big lie," and if so what do we do with this information? And then on the days we can look forward at what is to come, we ask: What is the shift that will happen once we can return to the streets, what will our embittered bodies gravitate towards? My hope is that it will be toward one another. 


\section{References}

Arendt, Hannah. 1958. The Human Condition. Chicago: University of Chicago Press.

Arendt, Hannah. 1963. On Revolution. London: Penguin Books.

Bou Aoun, Cynthia. 2020. "Reclaiming Public Space and Its Role in Producing the Revolution" Legal Agenda.

Joseph, Suad. 1997. "The Public/Private - The Imagined Boundary in the Imagined Nation/State/Community: The Lebanese case." Feminist Review 57 (73-92).

Kandiyoti, Deniz. 1988. "Bargaining with the Patriarchy." Gender and Society. 2, 3. Special Issue to Honor Jessie Bernard.

Osman, Bassam. 2020. "Weapons of Mass Destruction." Rusted Radishes. Beirut: American University of Beirut.

Nazzal, Maryam and Chinder, Samer. 2018. "Lebanon Cities' Public Spaces.” UN-Habitat Lebanon.

Pateman, Carole. 1983. "Feminist Critiques of the Public/Private Dichotomy." In Public and Private in Social Life, edited by. S.I. Benn and G.F. Gaus.

Schoonheim, Liesbeth. 2019. "The Productive Body: Rereading Hannah Arendt's Critique of Corporeality and Introspection." Philosophy Today, 63(2).

Smith, Zadie. 2020. Intimations: Six Essays. London: Penguin Books.

\footnotetext{
"Hur hur huriyye, badi 3eesh b'huriyye; mabadi sultit wazir wala sulta el dinniye
} 